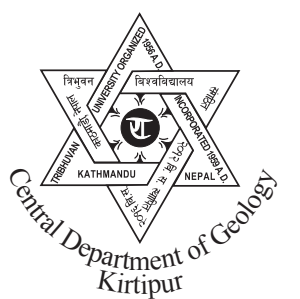

Bulletin of the Department of Geology

Bulletin of the Department of Geology, Tribhuvan University, Kathmandu, Nepal, Vol. 14, 2011, pp. 51-58

\title{
Inverted metamorphic zonation in the hanging and foot walls of the Mahabharat Thrust, Kathmandu-Trishuli area, central Nepal
}

\author{
Sobit Thapaliya and *Lalu Prasad Paudel \\ Central Department of Geology, Tribhuvan University, Kirtipur, Kathmandu, Nepal
}

\begin{abstract}
Geological study was carried out along the Pasang Lahmu Highway from Kathmandu to Trishuli Bazaar covering both the Lesser Himalayan autochthonous unit and the Kathmandu Nappe. The Lesser Himalayan rocks in the study area belong to the Kunchha Formation, Benighat Slate and the Robang Formation of the Nawakot Complex. The Kathmandu Nappe (Kathmandu Complex) comprises the Kalitar Formation, Gneiss Zone, Tistung Formation, Sopyang Formation and the Chandragiri Limestone.

Petrographic study was carried out in the samples representing all the lithological units along the Pasang-Lahmu Highway. The study shows that the Kunchha Formation belongs to the biotite zone. The overlying units (Benighat Slate and Robang Formations) belong to the garnet zone. It is a clear evidence of inverted metamorphic zonation at the foot wall of the Kathmandu Nappe. The rocks of the Kathmandu Complex above the Mahabharat Thrust north of Kakani also show an inverse metamorphic zonation, i.e., the garnet zone is overlain by the sillimanite zone. However, in the southern part, the metamorphic zonation is normal with biotite zone overlain by the chlorite zone. Although the inverted metamorphic zonation at the hanging wall of the Mahabharat Thrust may be related to the high temperature contact metamorphism by pegmatite injection, the inverted metamorphism at the footwall needs an explanation.
\end{abstract}

\section{INTRODUCTION}

In the Higher Himalaya and the Main Central Thrust zone (MCT zone), the metamorphic grade appears to increase northwards (structurally upwards) successively from chlorite to biotite, garnet, staurolite and to kyanite and to sillimanite zones. This is one of the interesting as well as controversial features of the Himalaya noted first by Richard Oldham in the Indian Himalaya in 1883 (quoted in Gansser 1964), and subsequently recognized by many geologists in other parts of the Himalaya (Gansser 1964; Le Fort 1975; Caby et al. 1983; Arita 1983; Sinha-Roy 1982; Hodges et al. 1988; Pệcher 1989 and many others). This feature has received much attention over the last three decades, and several models have been proposed to explain its origin (see a review by Sorkhabi and Arita 1997). Although it is more obviously observed in the Higher Himalaya and the MCT zone, inverted metamorphic

\footnotetext{
*Corresponding author:

E-mail address:lalupaude167@yahoo.com
}

zonation in the Lesser Himalaya has been described only by a few authors (Oliver et al. 1995; Sakai et al. 1999).

The Kakani Trishuli area is covered by high-grade metamorphic crystalline rocks of the Kathmandu Nappe lying over the low-grade metasedimentary rocks of the Lesser Himalaya along the Mahabharat Thrust (MT) (Hagen 1969, Arita et al. 1973; Stöcklin 1980; Stöcklin and Bhattarai 1981). The MT is interpreted as a direct continuation of the MCT (Stöcklin 1980; Stöcklin and Bhattarai 1981; Pêcher and Le Fort 1986). Some authors also suggest that the MT and the MCT are not the same thrusts and the Kathmandu Nappe is an exotic block (Rai et al. 1998, Upreti and Le Fort, 1999).

In the present study, geological mapping and petrogrpahic study was carried out along the Pasang Lahmu Highway from Kathmandu to Trishuli Bazaar (Fig. 1) covering both the hanging and foot walls of the MT. This paper presents the geological outline along the road and results of petrographic study. The 


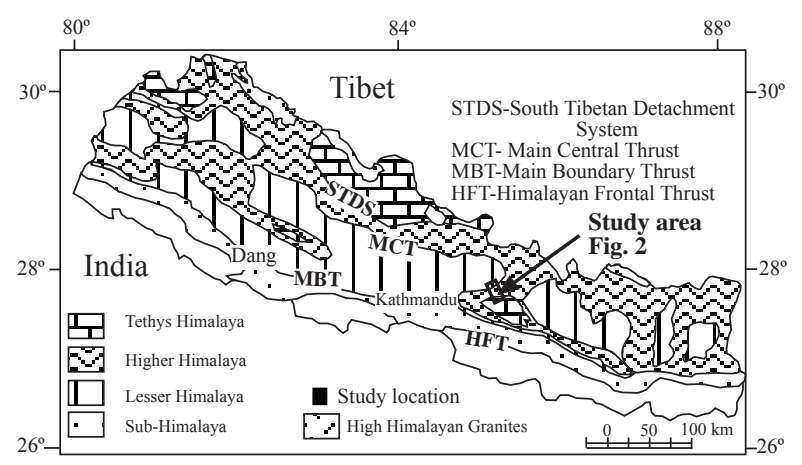

Fig. 1 Geological map of Nepal showing the location of the study area. study shows an inversion of metamorphic zones at the foot and hanging walls of the MT.

\section{GEOLOGICAL SETTING}

The study area lies in the northwestern part of the Kathmandu Nappe (Fig. 1) covering both the Lesser Himalayan autochthonous unit and the Kathmandu Nappe. The Lesser Himalayan rocks comprise Kunchha Formation of the Lower Nawakot Group and Benighat Slates, and Robang Formation of the Upper Nawakot Group (Stöcklin 1980; Stöcklin and Bhattarai 1981). The rocks of the Kathmandu Nappe are named as the Kathmandu Complex (Stöcklin 1980). In the study

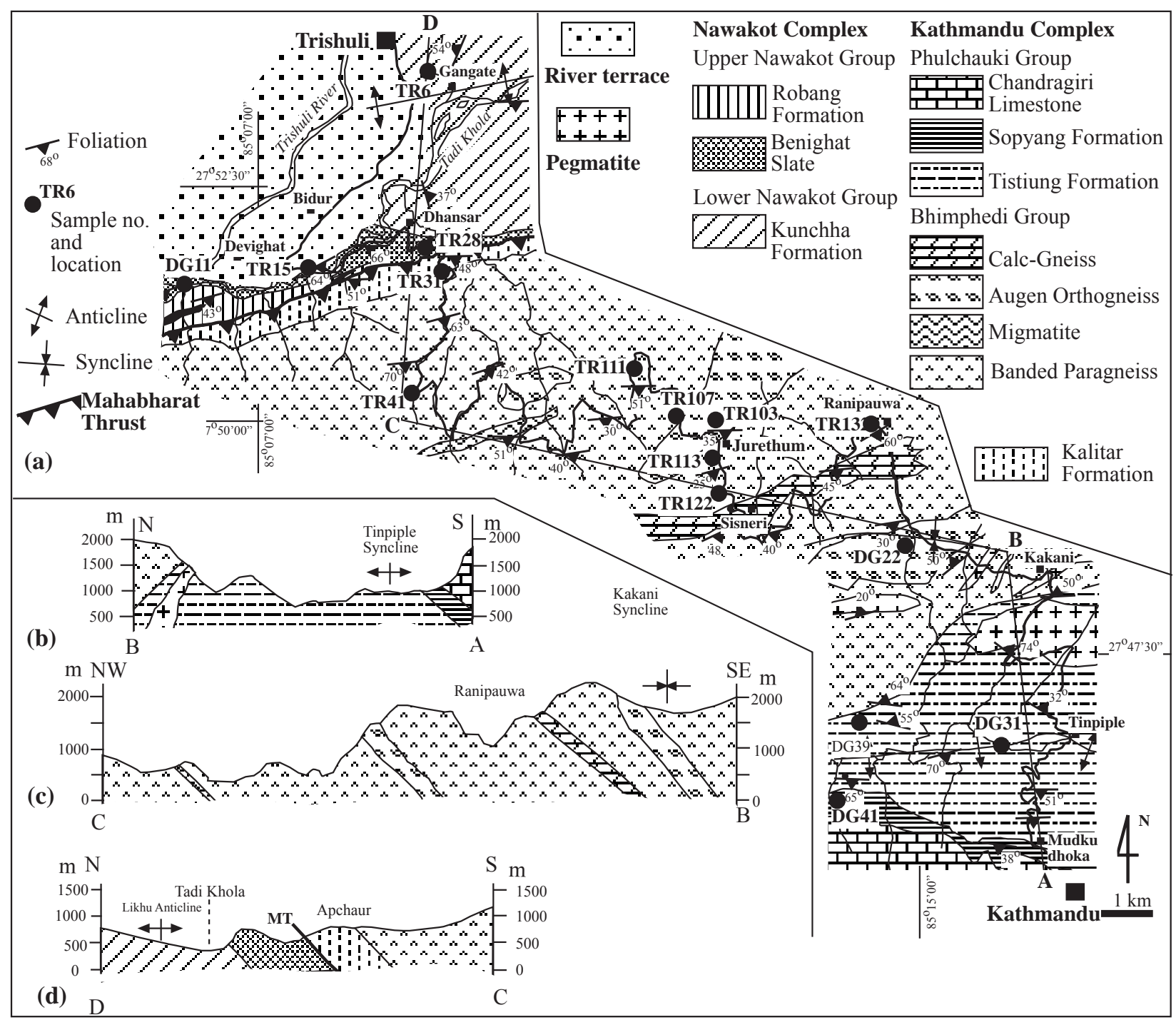

Fig. 2 (a) Geological map of the Kakani-Trishuli area prepared in the present study. Lower left corner shows the geological crosssections along A-B (b), B-C (c) and C-D (d). 


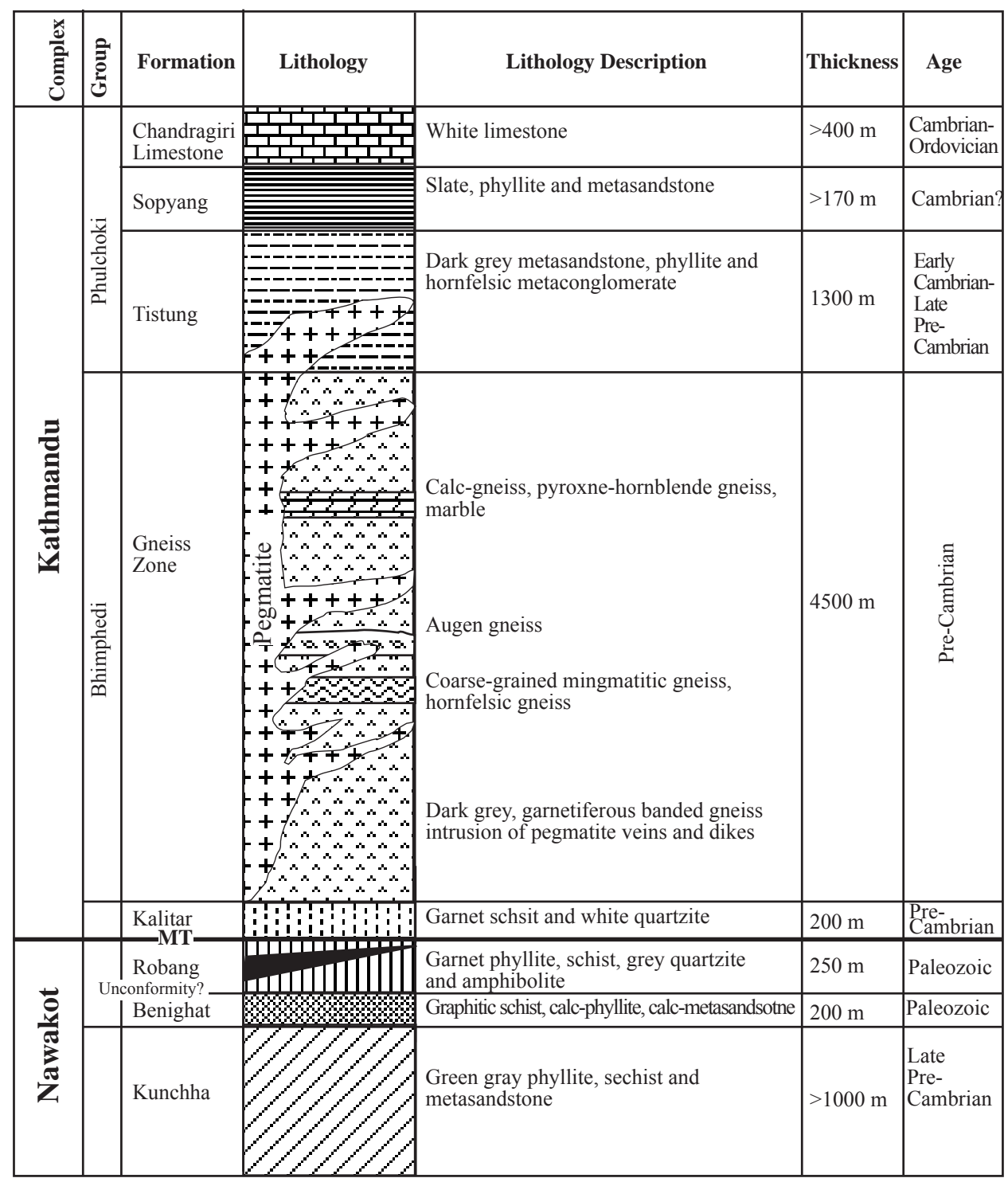

Fig. 3 Generalized lithostratigraphic column of the study area. MT: Mahabharat Thrust.

area, the Kalitar Formation of the Bhimphedi Group and the Tistung Formation, Sopyang Formation and the Chandragiri Limestone of the Phulchauki Group are exposed along the road (Fig. 2). The intervening units between the Kalitar and Tistung Formations have been obliterated by contact metamorphism and injection of pegmatite veins and dikes. A brief geology of the area is described below.

The Kunchha Formation, oldest unit of the Lesser Himalaya, is exposed at the northern part between Gangate and Dhansar villages. It comprises grey-green metasandstone, green-grey gritty phyllite, and chlorite schist with subordinate amount of white quartzite (Fig. 3). The Benighat Slate is characterized by thinly laminated calcareous phyllite, medium- grained calcareous sandstone and fine- to mediumgrained graphitic schist in the study area. Although the Benighat Slate should be followed by the Malekhu Limestone (Stöcklin 1980; Stöcklin and Bhattarai, 1981), it is missing in the studied section due to a probable unconformity and the Benighat Slate is overlain by the Robang Formation. It comprises mainly phyllite with subordinate amount of schist and quartzites. Some amphibolite bands are intercalated in the Robang Formation.

The Benighat Slate and the Robang Formation is discordantly overlain by the Kalitar Formation of the Bhimphedi Group along the MT. The Kalitar Formation is composed of coarse-grained, garnetiferous schist and white, medium- to thick-banded, coarse-grained 
quartzite. The Kalitar Formation is followed by a complex zone of banded paragneiss, augen orthogneiss, migmatitic gneiss and calc-gneiss intersected by a network of pegmatite veins and dikes. It is named as the Gneiss Zone in the present study. The Gneiss Zone is followed by metasandstone and phyllite of the Tistung Formation. The Tistung and Sopyang Formations and Chandragiri Limestone are observed in the southern part of the study area near Tinpiple and Mudku Dhoka, north-west of Kathmandu. The Tistung Formation consists of slates, phyllite and metasandstones. The Sopyang Formation shows mixed type of lithology such as grey slate, light grey limestone and subordinate amount of fine- to medium-grained, grey sandstone. The Chandragiri Limestone is made up of limestone with very thin bands of slate. Granitic pegmatites are intruded in the different level of the Gneiss zone and the Tistung Formation. Most of the pegmatitic veins show discordant relation with foliation and bedding plane.

\section{PETROGRAPHIC STUDY}

Samples of representative lithology and rock units were collected for petrographic study. The sample locations are shown in Fig. 2. Thin sections were prepared from the samples and observed under the petrological microscope. Petrogrphic characteristics of the samples have been described below. The mineral abbreviation is after Kretz (1983).

\section{Kunchha Formation}

G ritty phyllite (SampleNo.TR 6)

It contains the mineral assemblage $\mathrm{Bt}+\mathrm{Ms}+\mathrm{Pl}+\mathrm{Qtz}$. The grain size ranges from 0.25 to $1 \mathrm{~mm}$. Foliation is defined by phyllosilicates and elongated quartz grains. Ellipsoidal porphyroclasts of quartz are surrounded by the foliation forming asymmetric pressure shadows. Quartz grains usually show strong wavy extinction and deformation lamellae. Pressure solution is indicated by indented and sutured among the quartz grains (Fig. 4a). However, some of the quartz clasts are accompanied by polygonal aggregates of quartz.

\section{$B$ iotite Schist (Sam ple No.TR 15)}

The sample represents the biotite-bearing psammitic schist from the upper part of the Kunchha Formation. The mineral assemblage in this sample is $\mathrm{Bt}+\mathrm{Ms}+\mathrm{Chl}+\mathrm{Kfs}+\mathrm{Ab}+\mathrm{Chl}+\mathrm{Qtz}$. The modal composition is $66 \% \mathrm{Qtz}, 12 \% \mathrm{Kfs}, 15 \% \mathrm{Bt}, 8 \% \mathrm{Ms}$,
$2 \% \mathrm{Chl}$ and $1 \% \mathrm{Pl}$. The grain size ranges from 0.3 to $0.8 \mathrm{~mm}$. Foliation is marked by parallel arrangement of platy minerals and inequent grains of quartz and feldspar. A few domain of quartz exhibit relict granoblastic fabric deformed parallel to the foliation. The subhedral and anhedral grains of quartz are characterized by deformation lamellae.

\section{Benighat Slate}

G raph itic Sch ist (Sample No.TR 28)

It consists of predominantly graphitic materials $(>70 \%)$ with minor amount of quartz, muscovite and chlorite. The rock is very fine-grained. The alternating bands of light (quartz+feldspar) and dark layers (graphitic) mark the foliation plane.

\section{Robang Formation}

\section{Gametiferous Schist (Sam ple No.D G 11)}

It contains the assemblage $\mathrm{Grt}+\mathrm{Bt}+\mathrm{Ms}+\mathrm{Chl}+\mathrm{Kfs}+\mathrm{Ab}+\mathrm{Qtz}$. The modal composition is $22 \% \mathrm{Qtz}, 19 \% \mathrm{Kfs}, 8 \% \mathrm{Ms}, 33 \% \mathrm{Bt}$, and $18 \% \mathrm{Chl}$. The grain size ranges from 0.3 to $1.5 \mathrm{~mm}$. The phyllosilicate minerals are preferentially oriented defining the foliation. The garnet porphyroblast is characterized by the inclusions which are aligned parallel to the foliation. The garnet is overgrown across the foliation along the margins indicating postdeformational recrystallization of the rim (Fig. 4b). The alteration of biotite and garnet into chlorite is common showing the trace of retrogression.

\section{Kalitar Formation}

\section{$M$ icaceous Q uartzite (Sam ple No.TR 31)}

The micaceous quartzite contains an assemblage of $\mathrm{Bt}+\mathrm{Ms}+\mathrm{Kfs}+\mathrm{Ab}+\mathrm{Chl}+\mathrm{Qtz}$. The rock comprises more than $85 \%$ quartz. The anhedral to subhedral grains of quartz vary in size from $0.6 \mathrm{~mm}$ to $1.5 \mathrm{~mm}$. In average, the rock exhibits a granoblastic fabric. Some grains show strong pressure solution along the contact. Muscovite occurs both as detrital grains as well as recrystallized matrix. The associated schists with quartzite contain garnet porphyroblasts.

\section{Gneiss Zone}

Banded paragneiss (Sam ple No.TR 41, TR 111, and TR 107)

Sample No. TR 41 contains the assemblage 

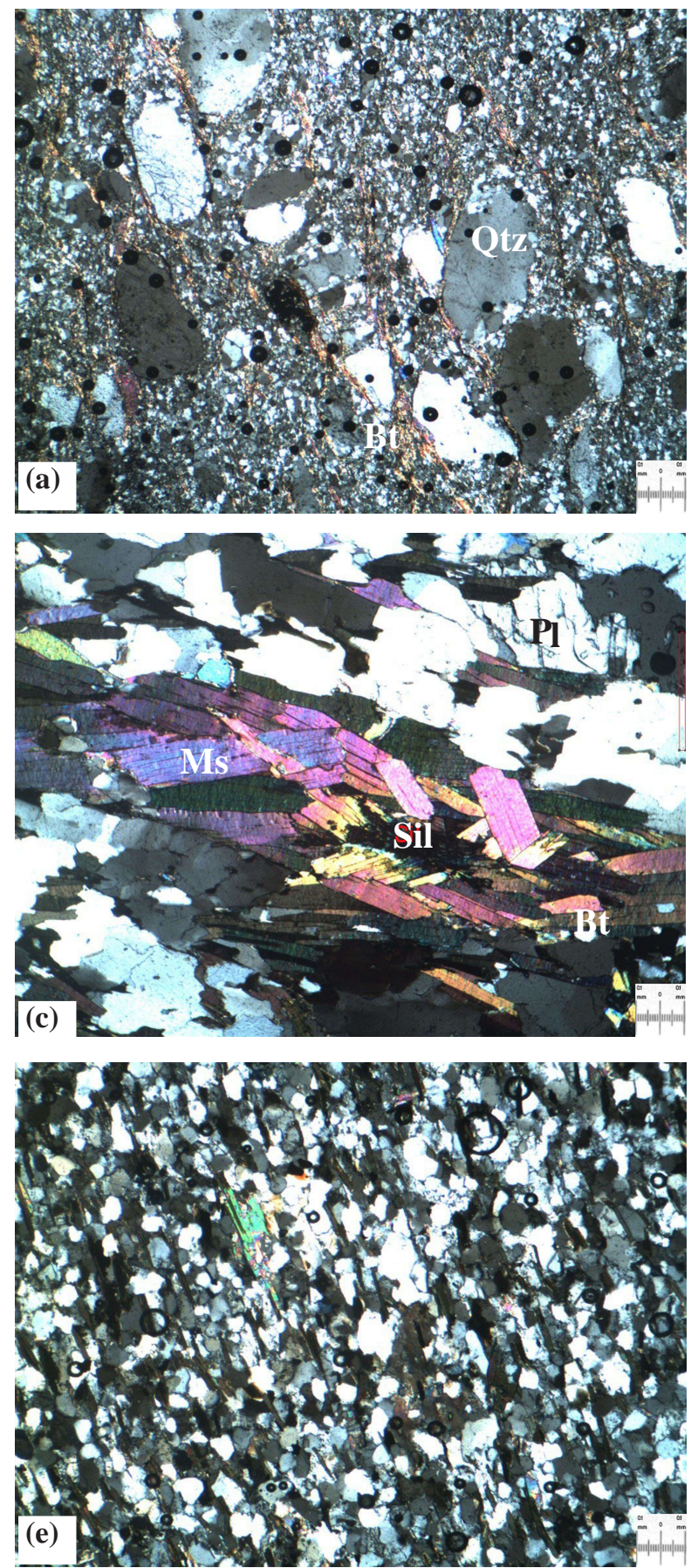
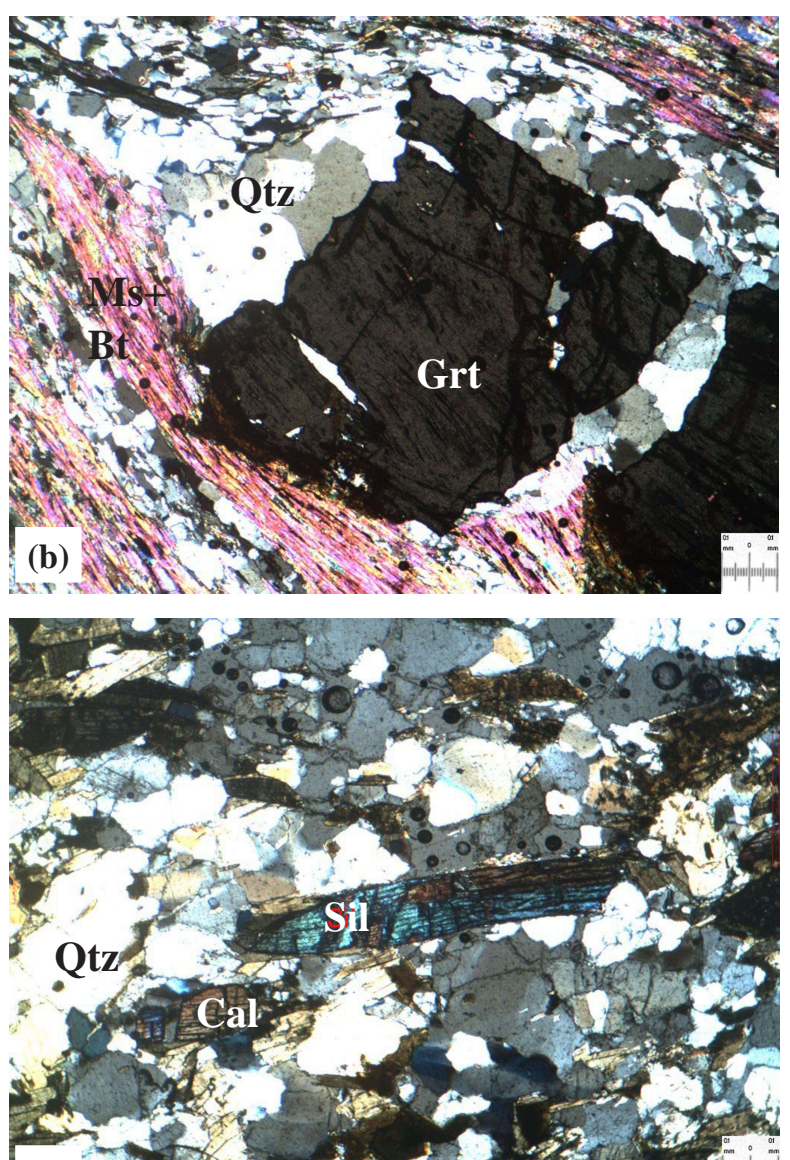

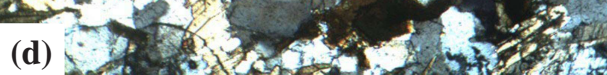

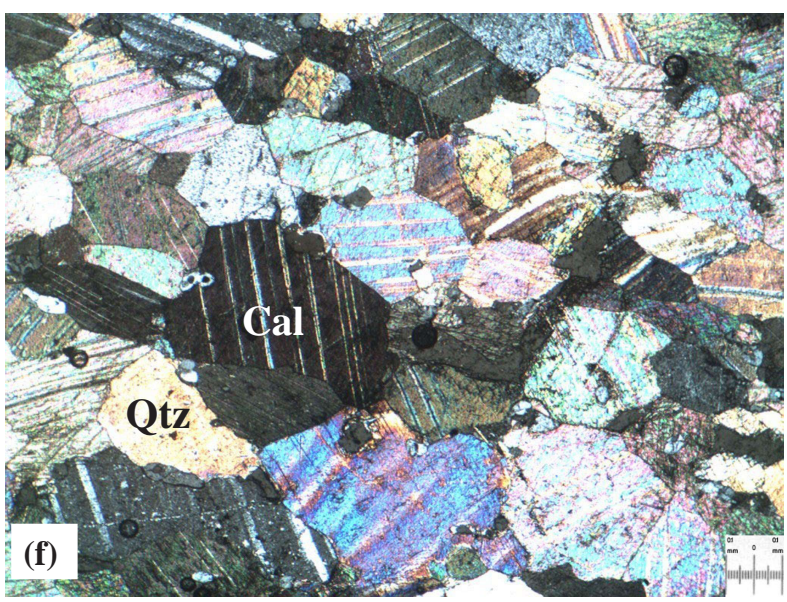

Fig. 4 (a) Gritty phyllite of the Kunchha Formation (TR6) showing elongated quartz porphyroclasts. (b) Garnet-bearing schist of the Robang Formation (DG11). (c) Banded gneiss (TR41) with fibrolitic sillimanite. (d) Augen orthogneiss (DG22) with sillimanite needle grown oblique to foliation. (e) Metasandstone of the Tistung Formation (DG31). (f) Marble of the Sopyang Formation (DG41) showing granoblastic texture.

$\mathrm{Sil}+\mathrm{Bt}+\mathrm{Ms}+\mathrm{Kfs}+\mathrm{Pl}+\mathrm{Chl}+\mathrm{Qtz}$. The other two samples (TR 111and TR 107) do not contain sillimanite. The samples are dominated by quartz (30\%) and feldspar
$(40 \%)$. Sillimanite is fibrous in nature and is grown oblique to the foliation (Fig. 4c). The grain size varies from $0.4 \mathrm{~mm}$ to $1.7 \mathrm{~mm}$. Foliation is developed by the 
preferred orientation of platy and some inequent grains. It contains the deformed porphyroclast of plagioclase and muscovite.

\section{$H$ omblende $G$ neiss (Sam ple No.TR 113)}

It contains the assemblage $\mathrm{Hbl}+\mathrm{Grt}+\mathrm{Bt}+\mathrm{Ms}+\mathrm{Pl}+\mathrm{Qtz}$. It shows bimodal grain size distribution varying from $0.6 \mathrm{~mm}$ to $1.7 \mathrm{~mm}$. The large grains of hornblende with inclusion of quartz and feldspar display a typical poikiloblastic fabric. The euhedral porphyroblasts of garnet with inclusion can be seen in thin section.

\section{Calc-gneiss (Sam ple No.TR 122)}

It contains the mineral assemblage $\mathrm{Bt}+\mathrm{Ms}+\mathrm{Pl}+\mathrm{Qtz}+\mathrm{Cal}$. Calcite makes over $70 \%$ of the mineralogy. In average the rock exhibits granoblastic fabric (Fig. 4d). The grain size varies from $1.9 \mathrm{~mm}$ to greater than $2.1 \mathrm{~mm}$. The granoblsatic mosaic of grain is somewhat deformed along the weakly developed foliation.

A ugen O ithogneiss (Sam ple N os.D G 22, TR 103)

The augen orthogneiss samples from the area contain the mineral assemblage $\mathrm{Sil}+\mathrm{Bt}+\mathrm{Ms}+\mathrm{Kfs}+\mathrm{Pl}+\mathrm{Qtz}$ (Fig. 4e). The modal composition is $50 \% \mathrm{Qtz}, 45 \% \mathrm{Kfs}, 3 \% \mathrm{Ms}$ and $2 \%$ $\mathrm{Bt}$,. The orthogneiss is very coarse-grained with grain size varying from $0.4 \mathrm{~mm}$ to $1.7 \mathrm{~mm}$. The weakly developed foliation is marked by preferrentially oriented phyllosilicate. The biotite flakes exhibit somewhat cross-cut relationship with the main foliation. Augens are formed by alkali feldspar and quartz. Perthitic texture is common throughout the section.

\section{Tistung Formation}

\section{$M$ etasandstone (Sam ple N o.D G 31)}

The metasandstone from the Tistung Formation contains mineral assemblage $\mathrm{Bt}+\mathrm{Ms}+\mathrm{Chl}+\mathrm{Kfs}+\mathrm{Pl}+\mathrm{Qtz}$. It is composed of about 50\% Qtz, 18\% Kfs and P1, $27 \% \mathrm{Bt}$ and about $1 \% \mathrm{Ms}$. Foliation is defined by parallel alignment of mica and deformed quartz and feldspar grains (Fig. 4e).

\section{Sopyang Formation}

\section{Lim estone (Sam ple No.D G 41)}

It contains mostly calcite $(>68 \%)$, quartz $\left(\bullet^{\prime} 98\right.$ $2 \%)$ and feldspar (15\%) grains. The foliation is very weak or absent. The rock is coarse-grained, and almost equigranular with granoblastic fabric (Fig. 4f).

\section{METAMORPHIC ZONATION}

A metamorphic zone is a mapable part of a metamorphic body in which rocks are of similar grade. Four metamorphic zones were identified based on index minerals in the study area (Fig. 5).

The chlorite zone is observed in the southern part of the study area around Mudku Dhoka region. This zone comprises upper part of the Tistung Formation, Sopyang Formation, and the Chandarigiri Limestone. The biotite zone is observed both in southern and northern parts of the study area. In the northern part, this zone is widely distributed in the Gangate-Trishuli area. The biotite zone covers both the Kunchha Formation and the Benighat Slate. In the southern part, the biotite isograd passes from south of Tinpiple and covers both the lower part of the Tistung Formation and the gneiss zone.

The garnet zone is found only in the northern part near the MT. The garnet isograd passes almost parallel to the Tadi Khola and do not follow the lithological boundaries. It covers both the upper part of the Benighat Slate, Robang Formation below the MT as well as the Kalitar Formaiton and gneiss zone above the MT.

The middle part of the study area is entirely covered by the sillimanite zone. The sillimanite isograd is observed in between Kakani and Ranipauwa in the southern part and near Belkot in the north (Fig. 5). The sillimanite zone covers the gneiss zone.

\section{DISCUSSION}

The disposition of metamorphic zones in the Kathmandu-Trishuli area do not a follow a pattern expected in a normal metamorphism. Usually, the metamorphic grade should increase stratigraphically and structurally downward, i.e., the older rock units should be in higher grade and younger units should show lower grade of metamorphism. Similarly rocks at structurally lower position should show higher grade of metamorphism compared to the rocks in the higher position.

In the study area, the footwall of the MT comprises the Kunchha Formation, Benighat Slate and the Robang Formation. In a normal metamorphism, Kunchha Formation should be at higher grade compared to the Benighat Slate and the Robang Formation. However, there the case is just reverse, i.e., the Kunchha Formation 


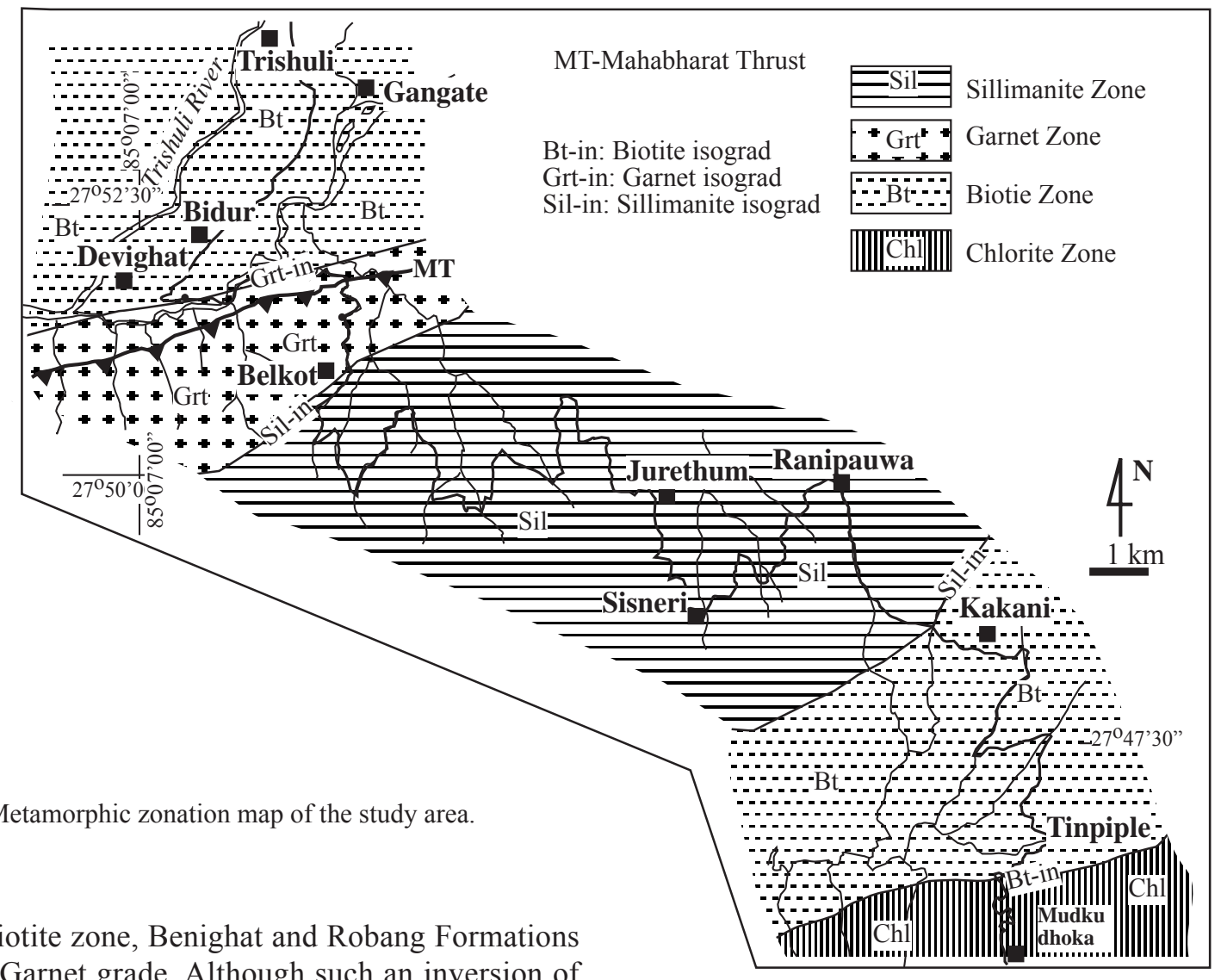

is at biotite zone, Benighat and Robang Formations are at Garnet grade. Although such an inversion of isograds is a commonly observed fact in the MCT zone (Le Fort 1975; Caby et al. 1983; Arita 1983; Sinha-Roy 1982; Hodges et al. 1988; Pécher 1989 and many others), this is the first report of clear evidence of inverted metamorphism at the footwall of the Lesser Himalayan crystalline nappe.

Above the MT, the garnet zone at the base is followed stratigraphically and structurally upwards by the sillimanite zone. The kyanite zone is missing here indicating high T/low P metamorphism. Therefore, the inverted metamorphic sequence seems continuous from the footwall to the hanging wall of the MT. However, in the southern part, the metamorphism is normal, i.e., the grade of metamorphism decreases from biotite zone in the Tistung Formation to chlorite zone in the Chandragiri Limestone.

The metamorphic pattern observed in this section of the Kathmandu Nappe is different from that observed in the Malekhu section where chlorite zone rocks of the Robang Formation at the footwall are abruptly overlain by the garnet zone rocks of the Raduwa Formation at the hanging wall of the MT (Stöcklin 1980). In the area, the metamorphic zonation is normal also in the hanging wall. The temperature of pegmatitic magma may range from $450^{\circ}$ to $650^{\circ} \mathrm{C}$ (Webber et al. 1999) which is above the stability field of sillimanite because the minimum temperature of stability for sillimanite is about $503^{\circ} \mathrm{C}$ at $3.2 \mathrm{Kbar}$ (Yardley 1990). Therefore, the confinement of sillimanite zone in the pegmatite injection zones may be regarded as due to high temperature contact metamorphism. However, garnet grade metamorphism in the Benighat Slates and Robang Formation needs explanation. Probably the "hot iron" model of Le Fort (1975) can explain this.

\section{CONCLUSIONS}

The Kathmandu-Trishuli area in central Nepal is occupied by the Nawakot Complex rocks in the north and the Kathmandu Complex rocks in the south separated by the Mahabharat Thrust (MT). The Nawakot Complex rocks in the area comprise the Kunchha Formation, Benighat Slate and the Robang Formation. The Kathmandu Complex rocks comprise the Kalitar Formation, Gneiss Zone, Tistung Formation, Sopyang Formation and the Chandragiri Limestone.

Four metamorphic zones were identified on the basis of petrographic study of samples representing all the 
lithological units along the road from Kathmandu to Trishuli. The oldest unit of the Lesser Himalaya, i.e., the Kunchha Formation belongs to the biotite zone whereas the younger units (Benighat Slate and Robang Formation) belong to the garnet zone showing a clear evidence of inverted metamorphic zonation at the footwall of the MT. The rocks of the Kathmandu Complex above the MT also show an inverse metamorphic zonation, i.e., garnet zone is overlain by the sillimanite zone. Although the inverted metamorphic zonation at the hanging wall of the MT may be related to the high temperature contact metamorphism by pegmatite injection, the inverted metamorphism at the footwall needs an explanation.

\section{ACKNOWLEDGEMETS}

We are thankful to the Central Department of Geology, Tribhuvan University for providing laboratory facility. Bishow Silwal helped in preparation of thin section and field work. We appreciate fruitful comments by S. M. Rai and K. K. Acharya.

\section{REFERENCES}

Arita, K., 1983. Origin of the inverted metamorphism of the lower Himalayas, central Nepal. Tectonophysics, p. 95 , pp. 43-60.

Arita, K., Ohta, Y., Akiba, C. and Maruo, Y., 1973. Kathmandu region. In: Hashimoto et al., 1973, Geology of the Nepal Himalayas, pp. 99-145.

Caby, R., Pécher, A. and Le Fort, P., 1983. Le grand Chevauchement central himalayen: nouvelles données su le métamorphisme inverse à la base de la Dalle du Tibet. Revue de Géographie physique et de Géologie Dynamique, Paris, v. 24, pp. 89-100.

Gansser, A., 1964. Geology of the Himalayas. Interscience Publisher, London, 289 p.

Hagen, T., 1969. Report on the Geological Survey of Nepal. Denkschr Schweizerischen Naturforschenden Gesellschaft, v. 81, 185 p.

Hodges, K.V., Hubbard, M.S. and Silverberg, D.S., 1988. Metamorphic constraints on the thermal evolution of the central Himalayan Orogen. Philosophical Transactions of the Royal Society of London, v. A326, pp. 257-280.

Kretz, R., 1983. Symbols for rock-forming minerals. American Mineralogist, v. 68, pp. 277-279.

Le Fort, P., 1975. Himalayas: the collided range, present knowledge of the continental arc. American Journal of Science, v. 275A, pp. 1-44.

Oliver, G.H.J., Johnson, M.R.W. and Fallick, A.E., 1995.
Age of metamorphism in the Lesser Himalaya and the Main Central Thrust zone, Garhwal India: results of illite crystallinity, 40Ar/39Ar fusion and $\mathrm{K} / \mathrm{Ar}$ studies. Geological Magazine, v. 132, pp. 139-149. http://dx.doi.org/10.1017/S0016756800011717

Pêcher, A., 1989. The metamorphism in the central Himalaya. Journal of Metamorphic Geology, v. 7, pp. 31-41.

Pêcher, A. and Le Fort, P., 1986. The metamorphism in central Himalaya: its relation with the thrust tectonics. Sciences de la Terre, Nancy, Mémoire, v. 47, pp. $285-$ 309.

Rai, S.M., Guillot, S., Le Fort, P. and Upreti, B.N., 1998. Pressure-temperature evolution in the Kathmandu and Gosainkund regions, central Nepal. Journal of Asian Earth Sciences, v. 16, pp. 283-298. http://dx.doi.org/10.1016/S0743-9547(98)00019-1

Sakai, H., Takigami, Y., Nakamuta, Y. and Nomura, H., 1999. Inverted metamorphism in the pre-Siwalik foreland basin sediments beneath the crystalline nappe, western Nepal Himalaya. Journal of Asian Earth Sciences, v. 17, pp. 727-739.

Sinha-Roy, S., 1982. Himalayan Main Central Thrust and its implications for Himalayan inverted metamorphism. Tectonophysics,v. 84, pp. 197-224. http://dx.doi.org/10.1016/0040-1951(82)90160-3

Sorkhabi, R.B., Arita, K., 1997. Toward a solution for the Himalayan puzzle: mechanism of inverted metamorphism constrained by the Siwalik sedimentary record. Current Science, v. 72, pp. 862-873.

St•cklin, J. ; Bhattarai, K.D., 1981. Geology of Kathmandu area and central Mahabharat Range, Nepal Himalaya. United Nations Development Programme, Mineral Exploration Nepal (DP/UN/NEP-73-019/3), 64 p.

Stöcklin, J., 1980. Geology of Nepal and its regional frame. Journal of Geological Society of London, v. 137, pp. 1-34.

Upreti, B.N. and Le Fort, P., 1999. Lesser Himalayan crystalline nappes of Nepal: problem of their origin. In: Macfarlane, A., Quade, J., Sorkhabi, R. (Eds.), Geological Society of America Special paper, v. 328, pp. 225-238.

Yardley, B. W. D., 1990. An introduction to metamorphic petrology. English Language Book Society/Longman, $248 \mathrm{p}$.

Webber, K.L., Simmons, W.B., Falster, A.U. and Foord, E.E., 1999. Cooling rates and crystallization dynamics of shallow level pegmatite-aplite dikes, San Diego County, California. American Mineralogist, v. 84, pp. 708-717. 